\title{
Model kepemimpinan otokratif manajemen sekolah dalam mendukung kinerja guru
}

\author{
Rahma Della $^{\left.1^{*}\right)}$, Muhammad Giatman ${ }^{1}$, Ernawati Ernawati $^{1}$ \\ ${ }^{1}$ Universitas Negeri Padang
}

\begin{tabular}{l} 
Article Info \\
\hline Article history: \\
Received May $08^{\text {th }}, 2021$ \\
Revised Jun $08^{\text {th }}, 2021$ \\
Accepted Jul $19^{\text {th }}, 2021$
\end{tabular}

\section{Keyword:}

Gaya kepemimpinan

Kepemimpinan otokratif

Kinerja guru

Manajemen

SMK

\begin{abstract}
Penelitian ini bertujuan menganalisis manajemen pengambilan keputusan sekolah untuk meningkatkan hasil kinerja guru SMKN 1 Bungo, mendeskripsikan peran kepala sekolah dalam manajemennya mendukung kinerja guru SMKN 1 Bungo, mendeskripsikan kewenangan kepala sekolah dalam manajemennya mendukung kinerja guru SMKN 1 Bungo, mendeskripsikan kontribusi signifikan gaya kepemimpinan manajemen sekolah dalam mendukung kinerja guru SMKN 1 Bungo melalui pendekatan deskriptif kualitatif studi kasus. Data didapatkan melalui proses wawancara, observasi partisipatif, dan studi dokumen. Subjek dalam penelitian yaitu kepala sekolah beserta wakil, dan guru-guru serta data dari dokumen yang diambil melalui observasi. Penelitian ini menggunakan uji kredibilitas data serta menggunakan triangulasi melalui model analisis data interaktif Milles dan Huberman. Dari hasil penelitian ini didapatkan peran penting manajemen kepala sekolah dalam pengambilan keputusan terhadap kewenangannya, kebijakan kepala sekolah merupakan betuk motivasi dalam pengevaluasian kinerja guru, Peran dan Kontribusi Gaya Kepemimpinan Otokratif kepala sekolah dalam memanajemenkan sekolaah sangat berpengaruh dalam menentukan kebijakan yang diambil demi perkembangan dan prestasi sekolah.
\end{abstract}

(C) 2020 The Authors. Published by IICET

This is an open access article under the CC BY-NC-SA license

(https://creativecommons.org/licenses/by-nc-sa/4.0)

\section{Corresponding Author:}

Rahma Della,

Universitas Negeri Padang

Email: rahma.dellasoelaiman@gmail.com

\section{Pendahuluan}

Perkembangan ilmu teknologi dan ilmu pengetahuan yang pesat, berdampak besar dalam dunia pendidikan. Salah satu dampak dari perkembangan tersebut adalah persaingan antar dunia pendidikan. Sehingga setiap satuan pendidikan harus meningkatkan mutu pendidikannya dengan memperbaiki kualitas input agar menghasilkan output yang luar biasa. Peningkatan mutu sekolah dapat dilakukan dengan pengelolaan sumber daya sekolah secara efektif (Fadila et al., 2020). Sumber daya yang dimaksud mencakup semua aspek, seperti kepala sekolah, pendidik, satpam, tata usaha, bendahara sekolah dan masyarakat. seluruh sumber daya manusia yang ada di sekolah harus mampu dikelola dengan baik oleh kepala sekolah, sehingga visi, misi, dan tujuan sekolah akan tercapai sesuai harapan seluruh warga sekolah. (Purnama, 2016).

Oleh karena itu, dalam mencapai keberhasilan sekolah, kepala sekolah, pendidik, satpam, tata usaha, bendahara sekolah dan orang tua peserta didik, dan pengurus lainnya harus melakukan kerja sama dengan baik. Guru yang berperan sebagai pendidik harus bertanggung jawab dengan pekerjaannya, memiliki komitmen dan rasa cinta terhadap profesinya. Kepala sekolah sebagai peran utama yang terlibat langsung 
dalam membaur, mengkoordinir, dan menyesuaikan sumber daya yang ada disekolah dengan gaya kepemimpinan, contohnya dalam pengambilan keputusan, delegasi kewenangan, dan pengelolaan interpersonal. Optimalisasi peran guru adalah segala sesuatu yang harus ada dalam diri seorang guru dalam meningkatkan kinerja guru secara optimal (Harahap \& D, 2019).

Pada dasarnya, setiap keputusan diambil pimpinan mempunyai konsekuensi, sebab, dan akibat dari keputusan itu sendiri. Baik atau buruknya kualitas pendidikan, tidak lepas dari keputusan yang diambil pimpinan. Dalam menarik keputusan yang tepat, satuan pendidikan perlu mengelola sistem dengan baik, dikarenakan setiap keputusan membutuhkan iformasi yang mendukung dengan akurat, tepat dan cepat. Peran interpersonal merukapakan suatu tugas yang didalamnya ada keterlibatan orang (baik bawahan yang didalam organisasi ataupun diluar organisasi), seperti dalam kegiatan konsultasi dengan kepala sekolah dengan guru dan karyawan berkaitan dengan tugas dan pekerjaan (Setyawan et al., 2017). Maka dari itu, kepala sekolah kepala sekolah harus secara langsung terlibat mengawasi guru dalam pembelajarannya. Kepala sekolah juga perlu terampil dalam mendelegasikan wewenang dan tugasnya, dimana proses ini meringankan juga memudahkan tugas-tugas tersebut, dan secara tidak langsung bawahan dapat mempelajari ilmu kepemimpinan dan mersa dihargai keberadaannya.kepala sekolah tidak hanya berperan mengelola sekolah supaya menjadi efektif dan efisien, tetapi kepala sekolah secara khusus juga harus mampu meningkatkan kinerja guru (Lumban Gaol \& Siburian, 2018).

Faktanya, dari data wawancara dengan pengurus sekolah, didapatkan permasalahan: dengan melihat kedisiplinan guru mempengaruhi kinerja dari guru itu sendiri. Berhasil atau gagalnya satuan pendidikan, teladan kepala sekolah, siswa, guru dalam proses belajar mengajar dipengaruhi oleh pimpinan sekolah dalam berinteraksi dengan bawahan. Penelitian ini merupakan penelitian hasil observasi pertama kali di SMKN 1 Bungo dengan latar belakang diperlukannya gaya kepemimpinan sekolah dalam mendukung kinerja guru untuk meningkatkan kualitas output pengajaran dan pendidik. Adanya persaingan antar satuan pendidikan dan terdapat guru yang kurang bertanggung jawab dalam menjani tugas sebagai seorang pengajar. Guru kurang disiplin dalam menjalani tugasnya, seperti datang terlambat dan tidak masuk mengajar pada jam pelaran dengan alasan tertentu.

Berdasarkan kenyataan dilapangan, kinerja guru SMKN 1 Bungo belum maksimal, guru kurang komitmen dalam bertugas karena banyak yang keluar masuk, sering terlambat, sering izin pada jam mengajar. Guru masih kurang dalam kemampuan membimbing siswa, sehingga pembimbing yayasan perlu membimbing terus menerus. Melihat dari kenyataan yang ada, diperlukannya suatu kebijakan dari kepala sekolah dalam upaya pengambilan kebijakan untuk mengatasi kurangnya kinerja dari guru tersebut karena kinerja guru berbanding terbalik dengan keercayaan orang tua yang menyekolahkan anaknya di SMKN 1 Bungo, dan jumlah siswa yang terus meningkat. Pengurus sekolah dituntut hadir di sekolah melakukan rapat bulanan membahas tanggung jawab guru sebagai pendidik, sekaligus menjadi anggota sistem manajerial sekolah.

Kepemimpinan merupakan variasi antara bakat alamiah dan kemampuan yang dipelajari (Setyawan et al., 2017). Model kepemimpinan seseorang merupakan bentuk aturan, tata perilaku yang diterapkan oleh seseorang pemimpin dalam mempengaruhi perilaku orang lain (Reza Aditya, 2010). Gaya kepemimpinan harus dipunyai oleh seoang pemimpin untuk mempengaruhi organisasi dalam mencapai tujuannya. Gaya kepemimpinan otokratik ialah suatu tindakan menurut kemauan sendiri, setiap pemikirannya dipandang benar, keras kepala dan bersifat paksaan. (Prayatna \& Subudi, 2016). Gaya kepemimpinan otokratif melibatkan 2 pihak yaitu pengikut dan pemimpin. Kekuasaan pada pemimpin dapat digunakan pada penerapan aturan atau saksi. Dalam hal ini, pemimpin memiliki kedudukan tertinggi dalam memonitoring dan mengontrol hal yang diinginkan guru. Peredaan penelitian ini dengan study sebelumnya terletak pada pimpinan yang menerapkan gaya otokratis menyesuaikan dengan stuasi dan lingkungan sekitar. Kepemimpinan otokratis merupakan jenis gaya kepemimpinan dalam organisasi yang mengutamakan kekuasaan dalam memutuskan kebijakan (Setiawan, 2017).

Gaya kepemimpinan otoriter mempunyai nilai lebih dalam pencapaian tujuannya, karena pemimpin yang memliki gaya kepemimpinan otoratik menggunakan kekuasaan dalam bertindak sehingga tidak ada yang dapat menghalangi langkahnya. Kelebihan dari gaya kepemimpinan otokratik ini dalam pencapaian prestasinya (Utami, 2018). Ketika pemimpin yang memiliki gaya otokratik mempunyai suatu target, maka itu harus didapatkan dan harus ada hasil yang sesuai. Pemimpin yang memiliki gaya otoratik dalam mengambil keputusan selalu hati-hati dan penuh pertimbangan,mereka sangat mementingkan target, kelemahan pemimpin ini yaitu bersifat sedikit kejam dan dingin. Mereka hanya fokus terhadap target tanpa memikirkan rintangannya.

Dalam suatu organisasi manajemen berperan sebagai proses tindakan perencanaan, penggerakan, pengorganisasian, dan pengendalian yang bertujuan untuk menentukan sasaran yang akan dicapai dengan 
sumber daya(manusia) yang ada (Hidayat, 2012). Melalui manajemen berbasis sekolah pendekatan perancangan kembali suatu organisasi sekolah yang dilakukan dengan cara memberikan kekuasaan dan kewenangan kepada partisipan sekolah untuk memajukan sekolah (Pratiwi, 2016). Sehingga bentuk manajemen berbasis sekolah ini melibatkan semua anggota disekolah dalam mencapai tujuan dengan memperhatikan kinerjanya. Dalam hal ini, kinerja guru berarti berkaitan dengan perancanaan, proses, dan hasil dalam kegitan pembelajaran.

Alasan peneliti memilih SMKN 1 Bungo adalah, karena SMKN 1 Bungo memiliki tujuan, prinsip, visi dan misi, dimana kepala sekolah memiliki peran penting dalam mencapai tujuan tersebut. Berdasarka paparan diatas, memberikan pertanyaan yang menjadi alasan penelitian, yaitu : bagaimana benuk gaya kepemimpinan yang efektik di SMKN 1 Bungo dengan karakteristik organisasi yang sedang mengallami perkembangan. Dari latar belakang tersebut, peneliti mengangat penelitian yang membahas tentang "Gaya Kepemimpinan Otokratis Manajemen Sekolah Dalam Upaya Meningkatkan Kinerja Guru SMKN 1 Bungo".

\section{Metode}

Penelitian ini melakukan pendekatan kualitatif. Pendekatan kalititatif yaitu yang mamahami obyek yang diteliti secara mendalam dengan tujuan mengembangkan konsep sensitivitas pada masalah yang dihadapi, menerangkan realitas yang berkaitan dengan penelusuran teori dari bawah serta mengeembangkan pemahaman akan satu atau lebih fenomena yang dihadapi (Gunawan, 2014). Desain penelitian menggunakan desain pendekatan kualitatif naturalistic dengan studi kasus sebagai strategi berdasarkan kecenderungan data yang didapatkan melalui studi penjajagan ke lapangan yang sesuai dengan tujuan penelitian untuk mengungkapkan suatu peristiwa dan dapat mengumpulkan data dari komponen yang mendukung manajemen sekolah dalam penerapan gaya kepemimpinan otokratif di SMKN 1 Bungo. Yang artinya penelitian ini berusaha untuk mengkaji data berkaitan dengan model gaya kepemimpinan otoktarif dalam manajemen guna mendukung peningkatan kinerja guru SMKN 1 Bungo dengan melakukan wawancara, dan melakukan pengamatan terhadap dokumen. Subjek dalam penelitian yaitu kepala sekolah beserta wakil, dan guru-guru serta data dari dokumen yang diambil melalui observasi. Penelitian ini menggunakan uji kredibilitas data serta menggunakan triangulasi melalui model analisis data interaktif Milles dan Huberman.

\section{Hasil dan Pembahasan}

Berdasarkan penelitian dilapangan, diperoleh hasil peneliatian yang peneliti rumuskan berdasar implementasi data yang ditemukan. Pertama, dalam manajemen pengambilan keputusan untuk meningkatkan kinerja guru SMKN 1 Bungo, Dari gambaran data dapat dideskripsikan bahwa keputusan yang diambil oleh kepala sekolah sebagi orang yang mempunyai kewenangan pada organisasi dalam mengahadapi suatu kebijakan sangat penting. Dalam pengambilan keputusan, manajemen sekolah yang dipimpin oleh kepala sekolah sangat berpengaruh dalam baik atau buruknya suatu kebijakan yang diambil. kepemimpinan kepala sekolah merupakan kegiatan mengambil keputusan atau merancangkan tindakan-tindakan strategis untuk mencapai tujuan organisasi yang ditetapkan sehingga dapat tercapai secara efektif dan efisien. (Aryawan, 2019). Kepemimpinan bersifat otokratis kepala sekolah cenderung bersifat yang mengandalkan kewenangannya sendiri. Pemimpin otokratis membuat keputusan sendiri karena kekuasaan terpusatkan dalam diri satu orang (Lufina, 2020). Dengan hal tersebut, kepala sekolah mepunyai tanggung jawab penuh terhadap wewenang dan keputusan yang diambil. Manajemen kepemimpinan di SMKN 1 Bungo dengan menerapkan gaya kepemimpinan otokratif dapat mendukung kinerja guru dengan pengambilan keputusan dan kebijakan sesuai dengan kehendak manajemen sekolah sesuai dengan tanggung jawab atas wewenang yang ada pada kepala sekolah.

Kedua, peran model kepemimpinan bersifat otokratif yang diterapkan kepala sekolah dalam mengatur manajemen guna meningkatkan kinerja guru SMKN 1 Bungo. Dari gambaran data dapat dideskripsikan bahwa keterampilan, kemampuan, da pengetahuan dasar atas pemahaman tanggung jawab guru terhadap pencapaian tujuan dalam pembelajaran perlu pemahan objek yang mendalam. Setiap keputusan yang diambil, setuju ataupun tidak, setiap kebijakan yang diputuskan harus dapat diterima dan dijalankan untuk mecapai tujuan dalam meningkatkan kinerja guru. Kepemimpinan adalah cara seorang pemimpin mempengaruhi perilaku bawahan, agar mau bekerja sama dan bekerja secara produktif untuk mencapai tujuan organiasasi (Andriani \& Tarigan, 2016). Dalam pengambilan keputusan, kepala sekolah menetapkan keputusannya sendiri tanpa melihat dan mendengar ide dari bawahan berdasarkan tujuan organisasi. Semakin bijak seorang pemimpin dalam memutusakan kebijakam, maka semakin tinggi pula tingkat kinerja bawahannya. 
Ketiga, pendelegasian kewenangan pada manajemen SMK N 1 Bungo dalam meningkatkan kinerja guru SMK N 1 Bungo. Dalam pendelegasian wewenang, mempunyai karakteristik dipengaruhi oleh pengawasan terhadap perbuatan dan tingkah laku bawahan. Berdsarkkan dari data hasil observasi, kepemimpinan di SMKN 1 Bungo tepat digunakan pada saat ssekolah membutuhkan keputusan yang cepat atau keadaan darurat. Dalam keadaan darurat, gaya kepemiminan otokratif ini diperlukan dalam embuat keputusan yang cepat dan tegas sehingga produktivitas tetap meningkat, khususnya meningkatkan kinerja guru SMKN 1 Bungo. Dalam kewenangannya, kepala sekolah memberikan tugas kepada guru untuk mencapai tujuan dan membuat keputusan yang tepat, sehingga guru tersebut dapat menerima delegasi secara eksplisit ataupun implisif akan membangkitkan rasa tanggung jawab. Dalam lingkup ini kepala sekolah memberikan wewenang atau tugas tanggung jawab kepada guru yang dipercaya sesuai dengan karakteristik pemberian wewenang.

Keempat, pengaruh signifikan dari gaya kepemimpinan otokratif manajemen sekolah dalam mendukung kinerja guru SMKN 1 Bungo. Berdasarkan hasil observasi, pengaruh dari gaya kepemimpinan kepala sekolah yang bersifat otokratif dalam mengatur manajemen sekolah dalam hal membuat kebijakan untuk prestasi sekolah mempunyai kekuatan yang sangat besar. kepala seolah melakukan analisis terhadap tujuan pekerjaan, syarat-syarat dan ketersediaannya pengajar. Setiap keputusan dari kepala sekolah dilakukan dengan menimbang kemajuan organisasi dan mendukung kinerja guru. Guru mempunyai kewajiban untuk melakukan dan menaati peritah kepala sekolah. Kontribus dan peran dari gaya kepemimpinan otokratif manajemen kepala sekolah mempunyai kekuatan dalam memutuskan suatu kebijakan tujuan sekolah dan prestasi sekolah. Kepala sekolah sebagai pemimpin dengan kepimimpinan yang otokratif berperan sebagai diktator dari guru-guru dalam mendukung kinerja guru. Guru sebagai bawahan wajib menjalankan perintah yang diberikan kepala sekolah. Dalam suatu organisasi pengambilan kebijakan, seorang pemimpin dapat menciptakan kondisi organisasi sesuai yang diharapkan oleh pimpinan. Di SMK N 1 Bungo, kepala sekolah melakukan analisa tujuan pekerjaan syarat-syarat pekerjaan serta ketersediaan tenaga pendidik.

\section{Simpulan}

Berdasarkan data hasil yang diperoleh pada penelitian tentang model kepemimpinan kepala sekoah terhadap manajemen sekolah dalam mendukung kinerja guru SMKN 1 Bungo dapat ditarik kesimpulan bahwa dalam pengambilan keputusan manajemen, yatu berkaitan dengan kebijakan yang ambil oleh kepala sekolah harus dilaksanakan dan diterima dengan tujuan meingkatkan kinerja guru. Manajemen yang baik sangat dibutuhkan untuk tujuan yang akan dicapai dan bentuk kinerja dari guru adalah kebutuhan dalam menetapkan tujuan. Kepala sekolah sangat berperan dalam pengambilan keputusan, kebijakan, dan aturan-aturan dalam memotivasi dan mengukur tingkat kinerja guru. Dalam keadaan darurat, gaya kepemimpinan yang tepat diguakan adalah gaya kepemimpinan otokratif, yaitu mengambil keputusan dengan tepat, cepat, dan tegas. Gaya kepemimpinan kepala sekolah mempunyai pengaruh yang sangat kuat dalam memutuskan kebijakan demi kebaikan dan kamajuan organisasi, meskipun keputusan tersebut diambil sipihak, bawahan harus mengkuti demi meningkatnya kinerja para guru.

\section{Referensi}

Andriani, \& Tarigan, U. (2016). Peranan Gaya Kepemimpinan Dalam Upaya Meningkatkan Prestasi Kerja di Dinas Kesehatan Provinsi Sumatera Utara. Jurnal Ilmu Administrasi Publik.

Aryawan, I. W. (2019). Strategi Kepemimpinan Kepala Sekolah Di Era Revolusi Industri 4.0 Berlandaskan Pada Konsep Panca Upaya Sandhi. Jurnal Ilmiah Ilmu Sosial. https://doi.org/10.23887/jiis.v5i2.22519

Fadila, R. N., Lutfiani, E. A., R, I. S., Veronika, N., Rachmanto, D., \& Arfinanti, N. (2020). Efektivitas pengelolaan sumber daya sekolah dalam meningkatkan mutu pendidikan. Jurnal Akuntabilitas Manajemen Pendidikan. https://doi.org/10.21831/jamp.v8i1.28997

Gunawan, I. (2014). Metode Penelitian Kualitatif: Teori dan Praktik. In Jakarta: Bumi Aksara.

Harahap, A. W., \& D, H. (2019). Optimalisasi Peran Guru Dalam Proses Pembelajaran. Jurnal Serunai Administrasi Pendidikan. https://doi.org/10.37755/jsap.v8i1.202

Hidayat, A. (2012). Pengelolaan Pendidikan (Konsep, Prinsip, dan Aplikasi dalam Mengelola sekolah dan Madrasah). Universitas Pendidikan Indonesia.

Lufina, L. (2020). Pengaruh Gaya Kepemimpinan Demokratis Terhadap Motivasi Kerja Karyawan Sales Bank Rakyat Indonesia Cabang Muara Teweh. Jurnal Ilmu Ekonomi (Manajemen Perusahaan) Dan Bisnis. https://doi.org/10.51512/jimb.v4i02.57

Lumban Gaol, N. T., \& Siburian, P. (2018). Peran Kepala Sekolah Dalam Meningkatkan Kinerja Guru. Kelola: Jurnal Manajemen Pendidikan. https://doi.org/10.24246/j.jk.2018.v5.11.p66-73

Pratiwi, S. N. (2016). Manajemen Berbasis Sekolah dalam Meningkatkan Kualitas Sekolah. EduTech Jurnal 
Ilmu Pendidikan dan Ilmu Sosial, 2(1). EduTech.

Prayatna, A., \& Subudi, I. (2016). Pengaruh Gaya Kepemimpinan Terhadap Stres Kerja Dan Kepuasan Kerja Karyawan Pada Fave Hotel Seminyak. E-Jurnal Manajemen Universitas Udayana.

Purnama, B. J. (2016). Optimalisasi Manajemen Sumber Daya Manusia Dalam Upaya Peningkatan Mutu Sekolah Human Resources Management To Improve. Jurnal Manajemen Pendidikan.

Reza Aditya, R. (2010). Pengaruh Gaya Kepemimpinan, Motivasi dan Disiplin Kerja Terhadap Kinerja Karyawan PT Sinar Santosa Perkasa Banjarnegara. Pengaruh Gaya Kepimpinan, Motivasi Dan Disiplin Kerja Terhadap Kinerja Karyawan Pt Sinar Santosa Perkasa Banjarnegara.

Setiawan, A. (2017). Pengaruh Gaya Kepemimpinan Partisipatif Terhadap Kinerja Karyawan Melalui Motivasi Kerja Dan Kepuasan Kerja. Agora.

Setyawan, J. D., Sumaryanto, T., \& Murwatiningsih. (2017). Gaya Kepemimpinan Otokratif Manajemen Sekolah dalam Mendukung Kinerja Guru SMK Pancasila di Kota Purwodadi. Educational Management.

Utami, S. S. (2018). Gaya Kepemimpinan Gubernur DKI Jakarta Berdasarkan Prinsip Tata Kelola Kepemerintahan Yang Baik (GCG). Liquidity. https://doi.org/10.32546/lq.v2i2.118 